J Cardiovasc Med (Hagerstown). 2013 Jan;14(1):1-18. doi: 10.2459/JCM.0b013e328351680f.

\title{
Methods to investigate coronary microvascular function in clinical practice.
}

Lanza GA, Camici PG, Galiuto L, Niccoli G, Pizzi C, Di Monaco A, Sestito A, Novo S, Piscione F, Tritto I, Ambrosio G, Bugiardini R, Crea F, Marzilli M; Gruppo di Studio di Fisiopatologia Coronarica e Microcircolazione, Società Italiana di Cardiologia.

Istituto di Cardiologia, Università Cattolica del Sacro Cuore, Rome, Italy. g.a.lanza@rm.unicatt.it

\section{Abstract}

A growing amount of data is increasingly showing the relevance of coronary microvascular dysfunction (CMVD) in several clinical contexts. This article reviews techniques and clinical investigations of the main noninvasive and invasive methods proposed to study coronary microcirculation and to identify CMVD in the presence of normal coronary arteries, also trying to provide indications for their application in clinical practice. 